\title{
ZAGAĐIVANJE I ZAŠTITA VAZDUHA, VODE I ZEMLJIŠTA
}

\author{
Milijana Đorđević \\ Univerzitet u Beogradu, Filološki fakultet
}

7 agađenost životne sredine i njenih elemenata: vazduha, vode i ze-mljišta je različita kroz epohe čovečanstva. Prema stepenu degradacije u razvoju ljudske civilizacije postoje tri epohe: poljoprivredna koja traje do 1850. godine, industrijska do 1950. godine i tehničko-tehnološka koja obuhvata drugu polovinu XX veka i traje do danas. U prvoj epohi degradacija je bila minimalna - zanemarljiva, a sa povećanjem stanovništva i sve veće aktivnosti čoveka u prirodi, povećava se i stepen degradacije prirodnih ekosistema i životne sredine u celini. Kasnije intenzivan razvoj industrije i proizvodnja radi sticanja profita, korišćenje fosilnih goriva kao energetskih izvora dovodi do ugrožavanja životne sredine u većem obimu, tako da se postavlja pitanje opstanka života na planeti Zemlji.

Republika Srbija kao članica svetske zajednice i sama oseća i trpi posledice zagađenja životne sredine, a naročito posle bombardovanja 1999. godine. U procesu tranzicije i pripremi za prijem u Evropsku uniju, sve više pažnje se posvećuje rešavanju brojnih ekoloških problema.

Ključne reči: zaštita životne sredine, zagađivanje vazduha, zagađivanje voda, zagađivanje zemljišta, mere zaštite

\section{Uvod}

Dosle II konferencije Ujedinjenih nacija o životnoj sredini i razvoju održanoj u Rio de Ženeiru 1992. godine i donetih dokumenata na njoj dolazi do buđenja svesti i većeg interesovanja za životnu sredinu i njenu zaštitu. To interesovanje za životnu sredinu se prvo javlja u najrazvijenijim industrijskim zemljama Zapada, a kasnije se interes širio, tako da je prisutan u svim zemljama sveta. Interes za životnu sredinu nije mimoišao ni Srbiju kao članicu svetske zajednice koja je izložena sopstvenim i planetarnim zagađenjem. Tako da se u poslednjih deset godina poklanja sve više pažnje problemima životne sredine i njene zaštite, a naročito radi prijema u Evropsku Uniju. Životna sredina dobila je odgovarajuće mesto u Ustavu zemlje, Zakonu i drugim normativno-pravnim aktima, formiraju se novi, stručni organi koji bi trebali da se profesionalno bave ovom problematikom.

\footnotetext{
* Dr Milijana Đorđević je docent.

1 Još je to nedovoljno i nije na istom nivou kao kod nekih razvijenih evropskih zemalja - zapažanje autora.
} 


\section{Zagađivanje životne sredine}

Zagađivanje je evoluiralo sa napretkom civilizacije od minimalnog zagađivanja vazduha (prva sagorevanja - požari), vode i zemljišta do današnjeg radioaktivnog zagađenja (nuklearne probe, akcidenti u nuklearnim centralama, upotreba nedozvoljenih borbenih sredstava u vojnim intervencijama) i zagađenja opasnim otrovnim supstancama iz raznih delatnosti. Izvori zagađenja životne sredine i njenih elemenata mogu biti:

- prirodni i

- veštački (antropogeni).

Prirodni izvori su svi procesi koje se odvijaju u biosferi mimo volje čoveka (vulkani, zemljotresi, kosmička prašina). Veštački (antropogeni) su produkti svih ljudskih delatnosti (vađenje i obrada mineralnih sirovina, termo i nuklearne elektrane, poljoprivreda, industrija, saobraćaja, turizma i drugih aktivnosti kao što su: sport, rekreacija i zagađivači iz domaćinstva).

„Zagađivanje životne sredine jeste unošenje zagađujućih materija ili energije u životnu sredinu, izazvano ljudskom delatnošću ili prirodnim procesima koje ima ili može imati štetne posledice na kvalitet životne sredine i zdravlja ljudi““ ${ }^{3}$

Dakle, zagađivanje predstavlja promenu životne sredine na „gore“ čime se menja njen prirodni sastav. Zagađivanje životne sredine je i planetarni problem s obzirom da se procesi zagađenja prenose vazdušnim strujanjem na velike udaljenosti (akcidenti: Černobil - 1986. i Fukušima - 2011). Kako su prirodni ekosistemi međusobno povezani uočava se uzročno-posledično zagađenje elemenata životne sredine.

\section{Zagađivanje vazduha}

Pojam zagađen vazduh podrazumeva prisustvo novih sastojaka do tada nepoznatih u uobičajenom sastavu, ili onih prisutnih kojima se količina povećava u enormnom obimu. Atmosferu čine: $78 \%$ azota, $21 \%$ kiseonika, 0,9\% argona i oko 0,34\% ugljen dioksida, $0,00116 \%$ ozona, dok vodonika, metana i plemenitih gasova ima samo u hiljaditim i milionitim delovima.

Zagađen vazduh je onaj koji sadrži štetne (zagađujuće) materije iznad maksimalno dozvoljene koncentracije (MDK) ${ }^{4}$ i takav vazduh ugrožava životnu sredinu, zdravlje ljudi i materijalna dobra.

Dakle, zagađen vazduh je onaj koji sadrži opasne-štetne materije iznade MDK čije prisustvo dovodi do remećenja ekološke ravnoteže, čime se ostvaruje negativan uticaj na sav živi i neživi svet, utiču na pojavu „kiselih kiša“, promenu klime i remećenje odnosa kiseonik-ugljendioksid.

Zagađenje vazduha i njegove posledice mogu biti lokalnog i globalnog karaktera (sve više je prisutan). Lokalno zagađenje je vezano za uže područje (grad, industrijski kompleks - Obrenovac, Pančevo, Šabac, Sevezo, Bopal, itd.). A globalno je uslovljeno stru-

\footnotetext{
${ }^{3}$ Zakon o zaštiti životne sredine, "Službeni glasnik RS", broj 135/04, član 3. stav 11.

${ }^{4}$ Pod maksimalno dozvoljenim koncentracijama štetnih materija u atmosferi, najčešće se podrazumeva ona koncentracija škodljivih gasova, para i aerosola u vazduhu koja pri određenom vremenskom, periodu izlaganja ne prouzrokuje oštećenje zdravlja.
} 
janjem vazdušnih masa koje zagađujuće materije prenose na veliku udaljenost od mesta nastanka (Kištimska katastrofa - 1957, Černobil - 1986, Fukušima - 2011). Od sredine XX veka javlja se i problem zagađenja radioaktivnim materijama, koji je prisutan i danas.

\section{Najveći zagađivači vazduha}

Intenzivan razvoj industrije i njihovih tehnoloških procesa je najveći zagađivač vazduha. Aerozagađenje zavisi od vrste industrijske grane. Kao najveći zagađivači smatraju se sledeće industrijske grane:

- energetski objekti (termoelektrane i nuklearne centrale),

- objekti crne i obojene metalurgije,

- hemijska, grafička, prehrambena industrija,

- industrija gvožđa, gume,

- industrija građevinskog materija,

- industrija plastike,

- industrija celuloze i papira,

- gazdinstva preduzeća drvne industrije,

- drumski, železnički, gradski, rečni i vazdušni saobraćaj,

- domaćinstva u selima i gradovima (individualna ložišta).

Zagađivači vazduha su različiti i oni dospevaju u vazduh kao produkti hemijskih reakcija i sagorevanja (fosilnih goriva) iz raznih industrija, komunalnih postrojenja, elektrana, motornih vozila, individualnih ložišta, oslobađaju se i iz rashladnih uređaja, sa tehnološko tretiranih poljoprivrednih površina i tako dalje.

\section{Izvori zagađenja vazduha}

Glavni izvori zagađenja vazduha u Srbiji su energetski sektor (posebno termoelektrane Obrenovac, Lazarevac, Kostolac, Kosovo), transportni sektor (motorna goriva i razna industrijska postrojenja, rudarski basen Bor. Drugi izvori zagađenja vazduha su rafinerije nafte locirane u Pančevu i Novom Sadu, proizvodnja cementa (Popovac, Kosjerić i Beočin), metalurški kombinati locirani u Pančevu i Smederevu, hemijska industrija u Subotici, Prahovu, Bariču, Kruševcu.

Uzroci zagađenja su: zastarela oprema, neprečišćavanje gasova iz dimnjaka ili slaba efikasnost filtera, loš kvalitet sirovina i niska energetska efikasnost, kao i neadekvatno funkcionisanje i održavanje postojećih postrojenja. Među najzagađenijim gradovima u Srbiji izdvajaju se Pančevo i Bor (koji zbog prisustva $\mathrm{SO}_{2}$, $\mathrm{Pb}$ i Cu i drugih polutanata nazivaju i „mrtvim“ gradom).

Zagađujuće materije koje dospevaju u vazduh-atmosferu su različite po sastavu, potiču od različitih izvora i imaju različito dejstvo na žive organizme. Po svojim karakteristikama izdvajaju se sledeće zagađujuće materije vazduha: oksidi sumpora $\left(\mathrm{SO}_{2}, \mathrm{SO}_{3}\right)$, oksidi azota $\left(\mathrm{NO}_{\mathrm{x}}\right)$, ugljenikovi oksidi $\left(\mathrm{CO}_{2}\right)$. hlorovodonična kiselina $(\mathrm{HCl})$, olovo $(\mathrm{Pb})$ i živa.

U Srbiji aerozagađenje je posledica emisije $\mathrm{SO}_{2}$ iz zastarelih industrijskih i termoenergetskih postrojenja u koja nisu ugrađeni sistemi za odsumporavanje dimnih gasova. Emi- 
sije azotnih oksida $\left(\mathrm{NO}_{\mathrm{x}}\right)$ poreklom od termoelektrana i industrije niže su po jedinici proizvedene energije u Srbiji nego u zapadnoevropskim zemljama, a u saobraćaju su nešto više. Olovo i živa su produkt sagorevanja fosilnih goriva, hemijske industrije, korišćenja vozila i deluju na nervni sistem.

Vazduh je na pojedinim mestima zagađen i toksičnim polutantima (kadmijum, benzol, azbest, radon i dr) koji deluju na sav živi svet i koji se prenose vazduhom, ali i hranom i vodom.

\section{Posledice zagađenja vazduha}

Zagađenje vazduha u atmosferi možemo posmatrati kroz:

- negativan uticaj na čoveka i njegovo zdravlje,

- ugrožavanje ostalih elemenata životne sredine (vode, zemljišta i ostali živi svet).

Čovek je veoma adaptabilan na nove uslove sredine, ali zagađen vazduh sve više predstavlja opasnost po njegovo zdravlje. Aerozagađenje ima akutne i hronične efekte na ljudsko zdravlje. Stalna izloženost zagađujućim materijama je opasna (primer Pančeva gde se javljaju razna oboljenja). U zavisnosti od koncentracije štetnih materija u vazduhu, različit je i efekat na zdravlje čoveka i zavisi od samog čoveka, njegovih godina i genetičkog nasleđa, da li boluje od nekih bolesti, od stepena fizičke aktivnosti i u novije vreme od stresnih situacija.

Vidljive posledice počinju od manjih iritacija očiju i respiratornog sistema, pa sve do hroničnih oboljenja, kao što su: bronhitis, astma, enfizem pluća, povećan procenat smrtnosti kod starijih osoba i obolelih osoba od drugih bolesti pa do nastanka raka pluća. Istovremeno slabi imunološki sistem i dovodi do povećanja podložnosti infekcijama, trovanju organizma, promeni psihičkog stanja, pojavi depresija i genetskih promena.

Pored čveka posledice zagađenog vazduha su vidljive i kod flore i faune. Iz atmosfere kroz atmosferske padavine zagađujuće materije stižu na površinu zemlje, vode. Akvatični organizmi (školjke, rakovi i ribe) unose in u sebe i dolazi do njihovog oštećenja, kroz lanac ishrane dolaze i do čoveka. Kod životinja je slično, one zagađujuće materije unose u organizam, delom preko disajnih organa a delom i hranom i vodom, što utiče na kvalitet mesa i mleka tih životinja. Biljni svet se takođe adaptirao na novom izmenjenom staništu ali su posledice vidljive na listovima i ostalim delovima biljaka. Različite koncentracije štetnih materija utiču na smanjenje fotosinteze, utiču na pH vrednost ćelijskog soka, a ovo izaziva propadanje biljaka.

\section{Mere za zaštitu vazduha od zagađenja}

Osnovni propis kojim se reguliše oblast zaštite vazduha u Republici Srbiji je Zakon o zaštiti životne sredine i njegov 24 član. Subjekti-zagađivači treba da obezbede sistem monitoringa za praćenje kvaliteta vazduha, emisije zagađujućih materija $\left(\mathrm{SO}_{2}, \mathrm{NO}_{\mathrm{x}}, \mathrm{CO}_{2}\right)$ na određenom mestu i u određeno vreme:

- da bi se aerozagađenje smanjilo mnoge fabrike i postrojenja prelaze na prirodni gas koji sadrži sumpor u tragovima,

- inoviranje postojećih tehnologija i oprema, na bazi „ekoloških“ kriterijuma,

- ugradnjom u postojeća industrijska postrojenja i toplane kolektore, elektrofiltere i drugo kojima će se smanjiti emisija zagađujućih materija u atmosferu, 
- u automobilskoj industriji izvršiti promene na nivou motora kojima će se smanjiti količina emisije zagađujućih materija u izduvnim gasovima automobila,

- u gradovima i industrijskim centrima je nužno korišćenje visokooktanskog benzina bez olova,

- vozni park Srbije je veoma star, ${ }_{13}^{1}$ svih vozila je starija preko 15 godina, a Nacionalna strategija životne sredine iz 2006. godine predlaže ukidanje olovnog goriva do 2010. godine,

- povremeni prestanak rada fabrika koje prelaze $\mathrm{GVI}^{6}$ koje su locirane u Pančevu, Kruševcu, Boru, Subotici, Zrenjaninu i Beogradu,

- u urbanizovanim sredinama potrebno je zasaditi što veći broj drveća (bagrem, bor, platane, belu topolu), pri tom voditi računa da su otporna na zagađen vazduh, jer su oni tzv. „pluća gradova“,

- povezivanje zelenih površina sa šumskim masivima čime se obezbeđuje dovoljno prodiranje svežih vazdušnih masa iz nenaseljenog prostora,

- dislociranje „prljavih“ industrija na periferiji gradova, ispuštanje zagađujućih materija iz fabrika vodeći računa o meteorološkim uslovima.

Mere zaštite vazduha obezbeđuju očuvanje atmosfere u celini, a ocena stanja zagađenosti vazduha vrši se prema Pravilniku o graničnim vrednostima, metodama merenja emisije, kriterijuma za uspostavljanje mernih mesta i evidencije podataka.

\section{Zagađivanje voda}

Od nastanka čoveka i razvoja ljudskog društva, značaj vode permanentno rase, a istovremeno i potrošnja raste a ujedno i stepen zagađenja vode se povećava. Zagađivanja su vremenom dobijala na kvantitetu i na kvalitetu, takao da je i pored značajne sposobnosti samoprečišćavanja-stanje vodnih resursa bivalo sve lošije. U razdoblju od 12. do 14. veka deo sliva reke Temze je bio u posebno teškoj situaciji, a sliv Rajne je od kraja 18. veka - do kada je smatran ukrasom zapadne Evrope - označavan kao njena kanalizacija. Areal ovih pojava se širio uporedo sa industrijskom revolucijom i pratećim procesima naseobinskog aglomeriranja i urbanizacije. ${ }^{7}$

U Zakonu o vodama stoji da „zagađivanje jeste direktno ili indirektno unošenje, kao rezultata ljudske aktivnosti, supstanci ili toplote u vazduh, vodu ili zemlju, a koje može biti štetno po ljudsko zdravlje ili kvalitet akvatičnih ekosistema (priobalni ekosistema), koje prouzrokuje štetu na materijalnim dobrima ili umanjuje ili ometa običajna i druga legitimna korišćenja životne sredine". ${ }^{8}$

Zagađivanje vodenih resursa je svaka čovekova aktivnost koja umanjuje upotrebljivost vode kao resursa. Dakle, zagađivanje vode je kvalitativna i kvantitativna promena njenih fizičkih, hemijskih i bioloških svojstava. Početkom sedamdesetih godina $20-o g$ ve-

\footnotetext{
${ }^{5}$ Zbog malog prosečnog ličnog dohotka stanovništva i dalje koristi to gorivo.

${ }^{6}$ Zakon o zaštiti životne sredine, "Službeni glasnik RS", br. 135/04, 36/09, 72/09 i 43/11.

${ }^{7}$ Milinčić, M.: Izvorišta površinskih voda Srbije- ekološka organičenja i revitalizacija naselja, Univerzitet u Beogradu - Geografski fakultet, Beograd, 2009, str. 22.

${ }^{8}$ Zakon o vodama, „Službeni glasnik RS“, br. 30/10, 93/12, i 101/16.
} 
ka 1/6 ukupnih vodnih resursa je već bila zagađena (Koronkevič, 1972:24) i taj proces se nastavlja i teži po mišljenju M. Lješevića (2000: 25) da pitka voda će predstavljati relativnu retkost u biosferi. Ta prognoza se nije ostvarila ali se kvalitet voda pogoršava, raste njeno zagađenje.

„Prema M. Milinčiću minimalna količina vode potrebna čoveku u zavisnosti od klimatskih uslova i iznosi 3,0-13,01/dan, gde fiziološke potrebe učestvuju sa 1,5-3,1/dan". ${ }^{9}$

$U$ našim klimatskim uslovima fiziološke potrebe za vodom se procenjuju na 2,5-3,1/dan. Stvarne dnevne potrebe vode su znatno veće od ovih vrednosti i variraju u zavisnosti od mnogih faktora, ${ }^{10}$ a pre svega od dostignutog nivoa životnog standarda, stepena sanitacije, potrošnje u industrijskim procesima, poljoprivredi i dr.

Najveći zagađivači voda

Sve vode možemo podeliti na: površinske, podzemne i meteorske. Postoje i druge podele. Po jednoj razlikujemo prirodne vode, morske ili slane, bočate ili poluslane, kopnene ili slatke (rečne, jezerske, podzemne, izvorske, mineralne), meteorske (kišnica, sneg, led) vode. Prema prof. Jovanoviću, vode se mogu podeliti prema:

a) mestu pojave u prirodi - prirodne vode,

b) stepenu prečišćenosti,

v) upotrebi

- voda za piće,

- voda za pranje,

- voda za tehnološki proces,

- voda za hlađenje,

- voda za parne kotlove (Jovanović, 2002: 30).

Klasifikacijom voda se vrši podela u klase, prema njihovoj nameni i određuju granične vrednosti osnovnih pokazatelja kvaliteta voda. Sve ove vode su uključene u hidrološki ciklus kruženja u atmosferi i pri tom dolazi do njihovog zagađivanja. Zajedničko za sve njih je da nisu odolele procesu zagađivanja.

Najveći zagađivači površinskih voda su:

- nafta i njeni derivati,

- proizvodi hemijske industrije,

- otpadne vode industrije,

- gradske otpadne vode iz kanalizacije, i

- deponije industrijskog komunalnog otpada.

U našoj zemlji voda je uglavnom zagađena delovanjem čoveka - ljudskog faktora. Zagađenje vode naftom nastaje prilikom bušenja i eksploatacije na naftnoj platformi i njenim transportom brodovima-tankerima.

„Procenjuje se da skoro $1 \%$ proizvodnje nafte iscuri, u toku transporta i njenog pretakanja, u okeane, mora i reke. Ova količina se procenjuje na 6-8 miliona tona godišnje“."

\footnotetext{
${ }^{9}$ Milinčić, M.: Izvorišta površinskih voda Srbije - ekološka organičenja i revitalizacija naselja, Univerzitet u Beogradu - Geografski fakultet, Beograd, 2009, str. 56.

${ }^{10}$ Potrošnja vode za pojedine svrhe zavisi od sledećih faktora: broja stanovnika, razvoja društva, razvijenosti industrije, klimatskih uslova, mogućnosti korišćenja vode jednom ili više puta, od tehnoloških postupaka za pojedine industrije itd.

${ }^{11}$ Vlatković, S.: Životna sredina i funkcije šuma, Javno preduzeće za gazdovanje šumama "Srbija šume" i Institut za šumarstvo, Beograd, 2001, str. 67.
} 
Glavni izvori zagađenja vode su neprečišćene industrijske i komunalne otpadne vode poljoprivredni odvodi. Voda se zagađuje i intenzivnom poljoprivrednom proizvodnjom, ${ }^{12}$ zbog primene mineralnih đubriva i pesticida, odlaganja otpada iz poljoprivrede i drugo.

NATO agresija na Srbiju 1999. godine vojni cilj uništavanja i razaranja su bile rafinerije i skladišta nafte (Rafinerija u Pančevu i Novom Sadu, bombardovana su i skladišta nafte u Somboru, Prahovu, Beogradu, Smederevu i Kraljevu) i njenih derivata i drugih industrijskih objekata, pri čemu je došlo do velikog zagađenja rečnih resursa i okolnog zemljišta usled prodora u njih toksičnih i opasnih materija u velikim količinama i dovele su do negativnih posledica po životnu sredinu i imaju posledice na sva živa bića.

Najzagađenije reke u Srbiji su: Toplica, Veliki Lug, Lugomir, Crni Timok i Bor (crvena reka - zbog prisustva metala bakra, dobila je crvenu boju).

Negativne posledice intenzivne poljoprivredne proizvodnje po životnu sredinu posebno su vidljive u ruralnim oblastima, jer one predstavljaju mesto za proizvodnju hrane. Primenom agrotehničkih mera - pesticida, đubriva i soli, samo 10-15\% primenjenih pesticida dospe do ciljnih štetočina, a ostatak završi u elementima životne sredine (vazduhu, vodi i zemljištu).

\section{Posledice zagađenja voda na zdravlje ljudi}

Vode se zagađuju na više načina a krajnji ishod zagađenja voda je oštećenje zdravlja (koje se manifestuje različito). Prisustvo mikroorganizama u vodi izaziva crevne infekcijedijareju, tifus pa sve do pandemskih bolesti (kolere).

Vode su zagađene patogenim mikroorganizmima, štetnim vodama (otpadne vode iz industrija, kanalizacione vode, mineralnim đubrivima (fosfati i nitrati).

\section{Mere za zaštitu voda od zagađenja}

Osnovni zakon koji reguliše različita pitanja vezana za vode je Zakon o zaštiti životne sredine i Zakon o vodama. Treba obezbediti sistem monitoringa za praćenje kvaliteta, odnosno stepena zagađenosti vode, a u okviru istog treba obezbediti praćenje kvaliteta, odnosno stepena zagađenosti vode, a u okviru istog treba obezbediti praćenje štetnih materija kroz duži ili kraći vremenski period, ${ }^{13}$ i inoviranje postojećih tehnologija ili oprema za prečišćavanje otpadnih voda.

Pored navedenog, neophodno je:

- izvršiti klasifikaciju i kategorizaciju vode - prema standardima o kvalitetu voda,

- preduzimanje sanacionih mera za zaštitu voda,

- izdavanje dozvole i odobrenja za izgradnju i rekonstrukciju objekata koji mogu zagađivati vodu,

- uvođenje poreza i taksa na otpadne vode,

- instaliranje uređaja za kontrolu zagađenosti voda, itd.

\footnotetext{
${ }^{12}$ Postoje tri osnovna sistema poljoprivredne proizvodnje: intenzivna ili klasična konvencionalna, održiva ili integralna i organska poljoprivredna proizvodnja.

${ }^{13}$ Istraživanje se vrši na period od tri godine.
} 


\section{Zagađivanje zemljišta}

Zemljište ima veliki značaj za život na Zemlji, za opstanak čoveka i razvoj ljudske civilizacije. Ono predstavlja izvor vode i mineralnih materija za celu fitocenozu, a putem lanca ishrane i za ostali živi svet uključujući i čoveka. Primenom pesticida i herbicida posle šezdesetih godina XX veka i drugih čovekovih aktivnosti uočava se povećanje njegovog zagađenja

Pod zagađivanjem zemljišta podrazumevaju se promene fizičkih, hemijskih i bioloških svojstava zemljišta, koje dovode do smanjenja njegove plodnosti.

.Zaqađenie zemlišsta ie proces odlaqania i unošenia opasnih i štetnih materiia na površinu zemljišta i u zemljište uzrokovano ljudskom aktivnošću ili prirodnim procesima“" ${ }^{14}$

Stav 9. istog zakona kaže: „zagađeno zemljište jeste zemljište u kome su ustanovljene koncentracije opasnih i štetnih materija koje su iznad graničnih vrednosti“.

\section{Načini ugrožavanja zemljišta}

Faktori ekološke krize: urbanizacija, industrijalizacija, porast stanovništva, širenje gradova i drugih naselja doveli su do ugrožavanja (zemljišta) a naročito poljoprivrednog zemljišta.

Postoje tri načina ugrožavanja zemljišta: degradacija (destrukcija), zagađivanje i isključenje iz korišćenja (što je jednako uništenju), obrušavanje obala usled poplava i odnošenje zemljišta-njegovo nestajanje u dolini plovnih reka (primer: Save-2014, V. Morave).

Degradacija je lakši a destrukcija teži oblik oštećenja zemljišta kojima se smanjuju površine a istovremeno i menja kvalitet zemljišta i njegova plodnost (uzroci su: erozija, klizišta, površinski kopovi, deponije smeća, salinizacija) i njime se narušava prirodna celina npr. skidanjem površinskih slojeva (površinski kopovi uglja, kamenolomi), zatim neplanska seča šuma i niskog rastinja.

\section{Posledice zagađenja zemljišta na zdravlje ljudi}

Posledice zagađenja zemljišta su: zagađivanje vode, zagađivanje zasađenih kultura, nemogućnost obnove biljnog pokrivača i sušenje šuma.

Proizvodnja hrane na zagađenom zemljištu ima za posledicu smanjenje prinosa po jedinici mere, nemogućnost sazrevanja plodova i slično, a istovremeno sve te biljke i životinje završavaju u naše kuhinje. Konzumiranje takve hrane dovodi do različitih posledica, razboljevamo se a nekad krajnji ishod može biti i smrt. Ne samo da smo zatrovali zemljište, već su otrovi prodrli i u podzemne vode, nalaze put i do naših bunara iz kojih pijemo vodu i dodatno se trujemo.

\section{Mere za zaštitu zemljišta od zagađenja}

Osnovne mere zaštite podrazumevaju smanjenje upotrebe zagađujućih materija u poljoprivredi i uopšte smanjenje i zagađenje vazduha i vode.

Zaštita zemljišta se sprovodi na osnovu Zakona o zaštiti zemljišta, usvojenih međunarodnih ugovora, propisanim merama i aktivnostima. Prema članu 13 ovog Zakona se predviđaju propisane mere i aktivnosti, a naročito:

\footnotetext{
${ }^{14}$ Zakon o zaštiti zemljišta, „Službeni glasnik RS“, br. 112/15.
} 
1. sistemskih praćenjem stanja i kvaliteta zemljišta u cilju očuvanja morfoloških, fizičkih, bioloških osobina,

2. praćenjem indikatora stanja i rizika od degradacije zemljišta,

3. praćenjem, predviđanjem i sprečavanjem aktivnosti koje bi mogle da budu ili jesu uzrok štetnih promena zemljišta,

4. planiranjem i integrisanjem mera zaštite u sektorske politike i planove,

5. utvrđivanjem prava i obaveza i odgovornosti vlasnika odnosno korisnika zemljišta,

6. praćenjem uticaja površinskih i podzemnih voda na zemljištu,

7. kontrolom, ograničavanjem i sprečavanjem unošenja zagađujućih opasnih i štetnih materija u ili na zemljištu,

8. primenom postupaka sanacije, remedijacije i rekultivacije zemljišta,

9. vršenjem inspekcijskog nadzora,

10. drugim nadzorom nad radom subjekata zaštite zemljišta.

\section{Zaključak}

Poslednjih decenija čovečanstvo se suočava sa sve većim zagađenjem životne sredine i njenih elemenata. Prvi signala ove zabrinjavajuće pojave iskazali su se kroz smanjenje biodiverziteta i klimatske promene. A da bi se rešavalo ovo goruće pitanje zaštite životne sredine prvo je neophodno utvrditi izvore zagađivanja, a zatim mere (preventive) koje je neophodno preduzeti s obzirom da je zagađenje izazvano antropogenim aktivnostima i prirodnim procesima u atmosferi, litosferi i hidrosferi.

Istovremeno, neophodno je i poštovanje zakonskih odredbi i uspostavljanje monitoringa praćenja zagađenja životne sredine iz svih izvora.

\section{Literatura}

[1] Vlatković, S.: Životna sredina i funkcija šuma, Javno preduzeće za gazdovanje šumama „Srbijašume“ i Institut šumarstva, Beograd, 2001.

[2] Vučićević, S.: Šuma i životna sredina i funkcija šuma, Javno preduzeće za gazdovanje šumama „Srbijašume“ i Šumarski fakultet Univerziteta u Beogradu, Beograd, 1999.

[3] Grupa autora: Enciklopedija životna sredina i održivi razvoj, Ekolibri i zavod za udžbenike i nastavna sredstva Srpsko Sarajevo, Beograd, 2003.

[4] Đorđević, M.: Uvod u ekologiju, Filološki fakultet, Beograd, 2011.

[5] Jovanović, P. M.: Ekologija vode, Viša tehnološka škola za nemetale odsek: tehnologija vode, Aranđelovac, 2002.

[6] Milinčić, A. M.: Izvorišta površinskih voda Srbije - Ekološka ograničenja i revitalizacija naselja, Univerzitet u Beogradu - Geografski fakultet, Beograd, 2009.

[7] Zakon o zaštiti životne sredine, „Službeni glasnik RS“, br. 135/04, 36/09, 72/09 i 43/11.

[8] Zakon o vodama, „Službeni glasnik RS“, br. 30/10, 93/12 i 101/16.

[9] Zakon o zaštiti vazduha, „Službeni glasnik RS“, br. 36/09.

[10] Zakon o zaštiti zemljišta, „Službeni glasnik RS“, br. 112/15. 
[11] Izveštaj o stanju životne sredine u SR Jugoslaviji za 1994. godinu, Beograd, 1996.

[12] Pravilnik o graničnim vrednostima emisije načina i rokovima merenja i evidentiranja podataka, „Službeni glasnik RS“, br. 30/97 i 35/97.

[13] Pravilnik o graničnim vrednostima emisije načina i rokovima merenja i evidentiranja podataka, „Službeni glasnik RS“, br. 30/97 i 35/97.

[14] Pravilnik o graničnim vrednostima emisije otpadnih voda, „Službeni glasnik RS“, br. 67/11.

[15] Pravilnik o graničnim vrednostima, metodama merenja emisije, kriterijuma za uspostavljanje mernih mesta i evidencije podataka, „Službeni glasnik RS“, br. 54/92.

[16] Uredba o graničnim vrednostima emisije zagađujućih materija u vazduhu iz postrojenja za sagorevanje, „Službeni glasnik RS“, br. 06/16.

[17] Uredba o graničnim vrednostima emisije zagađujućih materija u vode i rokovima za njihovo dostizanje „Službeni glasnik RS“, br. 67/11 i 48/12. 